\title{
Analyses of flood peak discharge in Cimadur river basin, Banten Province, Indonesia
}

\author{
Arniza Fitri ${ }^{1}$, Muhammad Shubhi Nurul Hadie ${ }^{2}$, Adelia Agustina ${ }^{1 *}$, Dian Pratiwi ${ }^{1}$, Susarman ${ }^{1}$, Galuh Pramita $^{1}$, and \\ Salah H. R. Ali ${ }^{3}$ \\ ${ }^{1}$ Department of Civil Engineering, Faculty of Engineering and Computer Science, Indonesian Technocrat University, Bandar \\ Lampung, Lampung 35132, Indonesia \\ ${ }^{2}$ Department of Civil Engineering, Faculty of Engineering, Andalas University, Padang 25164, Indonesia \\ ${ }^{3}$ Precision Engineering Division, National Institute for Standards, Giza (12211-136), Egypt
}

\begin{abstract}
Cimadur river basin is one of the most important catchment areas in Lebak District, Banten Province. For the past few years, the catchment has experienced floods during the rainy season. The big issue of flooding has been recorded recently in December 2019 which has caused damage and negative impacts to the local people and surrounding community. This study aims to analyze the possibility of flood peak discharges in the catchment area of the Cimadur river. The flood discharges are calculated for $2,5,10,25,50$, and 100 years return period based on the daily rainfall data from the year 2011 to 2020. The rainfall and land use data are obtained from PT Saeba Consultant. In this study, the hydrological analyses are including 1) analyses of average annual rainfall using the Thiessen method; 2) analyses of rainfall distribution and estimation of design rainfall by considering three methods involving: Log-Normal, Log Pearson Type III, and Gumbel Type 1; and 3) analyses of flood discharges by adopting Nakayasu Synthetic Hydrograph Unit (SHU). The rainfall distribution analyses show that the Log Pearson Type III provided the best fit. Based on the flood peak discharges analyses, the results show that the flood discharges for the $5,10,25$, and 50 years return period in the Cimadur river basin are $470.71 \mathrm{~m}^{3} / \mathrm{s}, 560.16 \mathrm{~m}^{3} / \mathrm{s}, 698 \mathrm{~m}^{3} / \mathrm{s}$, and $820.4 \mathrm{~m}^{3} / \mathrm{s}$, respectively.
\end{abstract}

\section{Introduction}

Flooding is the most frequent natural disaster that occurred in Indonesia in the past few decades, mostly triggered by extreme rain during the rainy season $[1,6]$. However, the occurrences of flooding are not only natural but can be aggravated due to socio-economic factors such as urbanization and development activities which could result in larger flood-prone areas [7, 9].

Regarding flood risk reduction and prevention in a local region, estimation of flood peak discharges in a local area is becoming necessary [9]-[11]. Estimation of the flood peak discharges could be helpful in properly designing the various engineering structures in the river basin $[12,15]$.

Cimadur river basin is one of the most important catchment areas in Lebak District, Banten Province, Indonesia. The land-use change activities such as converting the forest into residential areas and rice fields around the river have triggered the flood occurrences in this catchment for the past few years (Fig. 1). One of the biggest flood events in the Cimadur river basin has been experienced in December 2019 which has caused damage

\footnotetext{
* Corresponding Author: adeliagstna@gmail.com
}

and negative impacts to the local people and surrounding community.

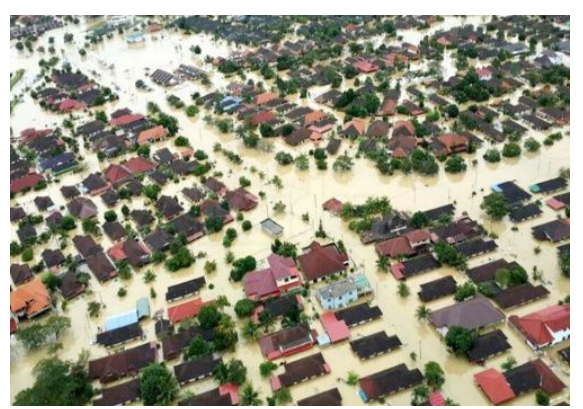

Fig. 1. One of the flood events occurred in the Cimadur river basin

To reduce and control the flood events in the Lebak district, the local government and the local water resource managers are going to design the various engineering structures on the Cimadur river catchments. Due to the importance of flood peak discharges estimation in designing the engineering structures in the Cimadur river basin, therefore, this study aims to analyze the possibility of flood peak discharges in the catchment area of the 
Cimadur river. The flood discharges are calculated for 2 , $5,10,25,50$, and 100 years return period.

\section{Materials and Methods}

\subsection{Study Area}

This study is carried out in the catchment of Cimadur river, Lebak District, Banten Province, Indonesia. Cimadur river catchment as shown in Fig. 2 is geographically located between $6^{\circ} 40^{\prime \prime} \mathrm{S}$ to $6^{\circ} 55^{\prime \prime} \mathrm{S}$ (latitudes) and $106^{\circ} 14^{\prime \prime} \mathrm{E}$ to $106^{\circ} 25^{\prime \prime} \mathrm{E}$ (longitudes). The total area of the Cimadur river catchment is approximately about $210 \mathrm{~km}^{2}$. The catchment is influenced by 2 monsoon seasons during the year that is rainy season and the dry season. The area receives one cycle of rainfall during the rainy season which runs from April to October in the year.

The topography condition in the Cimadur river catchment is a moderate slope with an elevation between 0 and $500 \mathrm{~m}$ above MSL. Local people in this catchment are mostly making a living as a farmer [16].
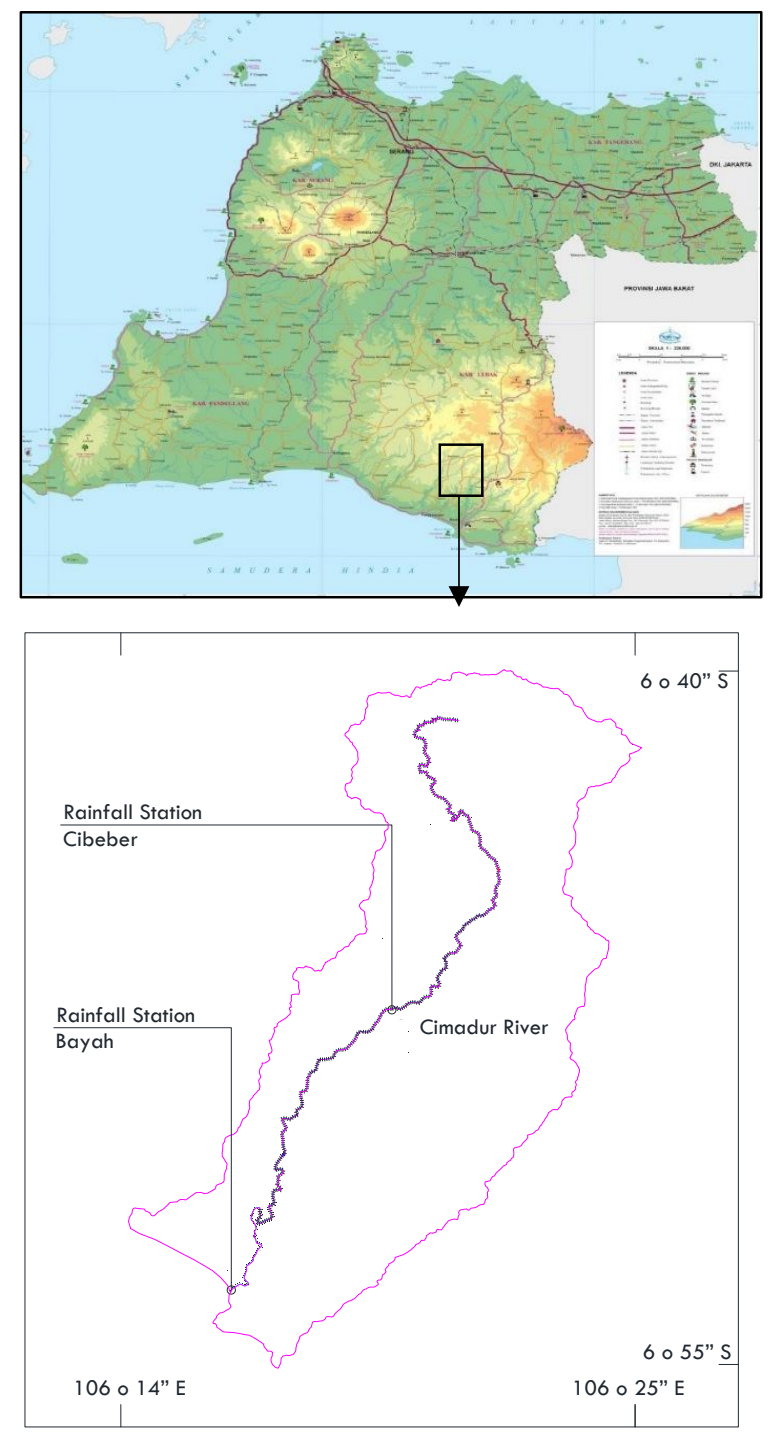

Fig. 2. Location of the study area

\subsection{Data Collection}

For estimation of flood peak discharges, the required data is consisting of rainfall data and land use data. There are two rainfall stations in the catchment of the Cimadur river, which are Bayah station and Cibeber station. In this study, rainfall data and land use data are obtained from PT. Saeba Konsulindo Serang, Banten. Rainfall data from both rainfall stations (Bayah station and Cibeber station) are taken for ten years period (2011 to 2020). Based on the available data, the maximum daily rainfall per year is presented in Table 1. Apart from that, Table 2 describes the land use condition in the Cimadur river basin in the year 2019 based on research done by PT Saeba Konsulindo.

Table 1. Maximum daily Rainfall per year

\begin{tabular}{|c|c|c|c|}
\hline No & Year & $\begin{array}{c}\text { Rainfall data at } \\
\text { Bayah Station } \\
(\mathbf{m m}), \mathbf{P 1}\end{array}$ & $\begin{array}{c}\text { Rainfall data at } \\
\text { Cibeber Station } \\
(\mathbf{m m}), \mathbf{P 2}\end{array}$ \\
\hline 1 & 2011 & 137 & 75 \\
\hline 2 & 2012 & 128 & 91 \\
\hline 3 & 2013 & 185 & 112 \\
\hline 4 & 2014 & 121 & 97 \\
\hline 5 & 2015 & 101 & 71 \\
\hline 6 & 2016 & 115 & 93 \\
\hline 7 & 2017 & 120 & 71 \\
\hline 8 & 2018 & 131 & 128 \\
\hline 9 & 2019 & 112 & 201 \\
\hline 10 & 2020 & 136 & 184 \\
\hline
\end{tabular}

Table 2. Landuse Condition in Cimadur river basin in years of 2019

\begin{tabular}{|c|l|c|c|}
\hline No & $\begin{array}{l}\text { Landuse } \\
\text { area }\end{array}$ & Area (ha) & Percentages (\%) \\
\hline 1 & forest & 7284 & $34.65 \%$ \\
\hline 2 & River & 90 & $0.43 \%$ \\
\hline 3 & residential & 221 & $1.05 \%$ \\
\hline 4 & ricefield & 3691 & $17.56 \%$ \\
\hline 5 & $\begin{array}{l}\text { Mix } \\
\text { garden }\end{array}$ & 8952 & $42.58 \%$ \\
\hline 6 & bush & 744 & $3.54 \%$ \\
\hline 7 & bare land & 40 & $0.19 \%$ \\
\hline
\end{tabular}

\subsection{Hydrological Analyses}

In this study, hydrological analyses are carried out to estimate the flood peak discharges in the Cimadur river basin for $5,10,25,50$, and 100 years return period. There are several stages in hydrological analyses including analyses of average annual rainfall, analyses of rainfall frequency distribution, estimation of design rainfall, and analyses of flood peak discharges. The detailed description for those analyses are following: 


\subsubsection{Analysis of average annual rainfall}

The average annual rainfall is analyzed by approaching the Thiessen method. Here, one rainfall station from outside of the Cimadur river basin is included to draw the polygon and to get the total areas influenced by each rainfall station. Fig. 3 shows the area division for the calculation of average annual rainfall. The calculation is further follows the equation below [17] :

$$
P=\frac{A 1 p 1+A 2 p 2+A 3 p 3+\cdots+A n p n}{A 1+A 2+A 3+\cdots+A n} .
$$

Where:

$$
\begin{array}{ll}
\mathrm{P} & =\text { the average value of annual } \\
& \text { rainfall } \\
\mathrm{P} 1, \mathrm{p} 2, \ldots, \mathrm{pn} & \text { maximum daily rainfall for each } \\
& \text { rainfall station }(1,2, \ldots, \mathrm{n}) \\
\mathrm{A} 1, \mathrm{~A} 2, \mathrm{~A} 3, \ldots \mathrm{An} & =\text { area influenced by each rainfall } \\
& \text { station }(1,2, \ldots, \mathrm{n} .)
\end{array}
$$

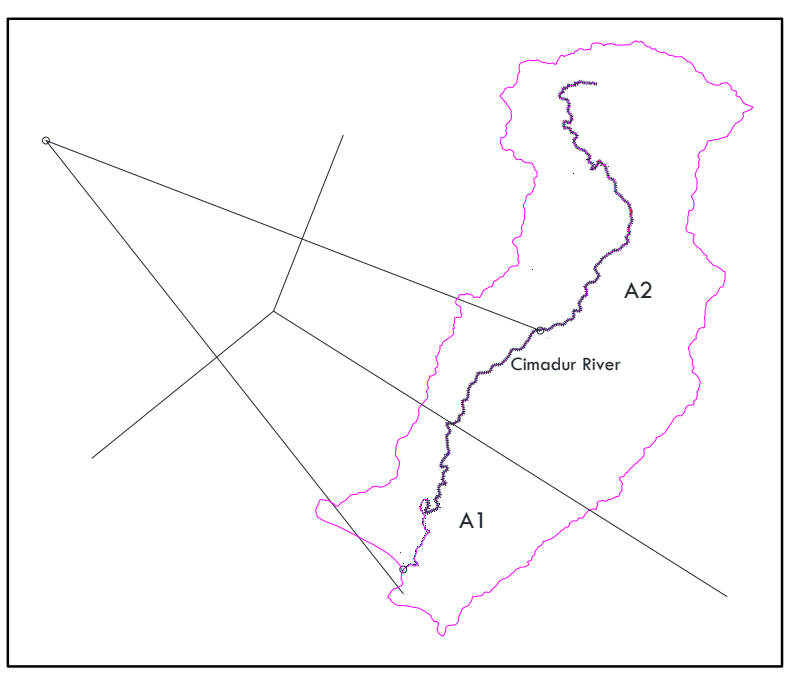

Fig. 3. Area division for each rainfall station

Based on polygon drawing, it can be described that the total area influenced by Bayah' station (A1) is $50.4 \mathrm{~km}^{2}$ ( $24 \%$ from the total catchment of Cimadur), while the total area influenced by Cibeber' station (A2) is $159.6 \mathrm{~km}^{2}$ (76\% from the total catchment of Cimadur).

\subsubsection{Analyses of rainfall frequency distribution and estimation of design rainfall}

Concerning the estimation of design rainfall and analyses of rainfall frequency distribution, three methods are considered to be examined in this study including the Log-normal method, extreme Gumbel type 1 method, and Log person type III method.

The equation used for calculation of design rainfall in the Log-normal method is as follows [17]:

$$
\log X_{T}=\log \bar{X}+\mathrm{k} \cdot \mathrm{Sx} \cdot \log X
$$

Where:

$\log X_{T} \quad=$ design rainfall for $\mathrm{T}$ years return period $\log \bar{X} \quad=$ the logarithms average of rainfall data

$\bar{k} \quad=$ coefficient factor

SxLogX $=$ standard deviation

Further, the equation used for calculation of design rainfall in the Gumbel type 1 method is as follows [17]:

$$
X_{T}=\bar{X}+S . K \text {. }
$$

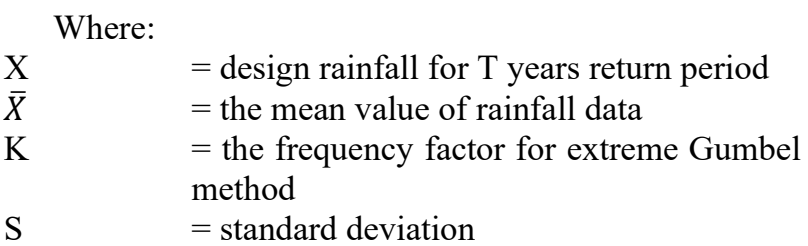

$$
\begin{gathered}
K=\frac{Y t r-Y n}{S n} \ldots \ldots \ldots \ldots . . . . . \\
Y t r=-\operatorname{In}\left\{-\operatorname{In} \frac{T r-1}{T r}\right\} .
\end{gathered}
$$

Where:

$$
\begin{array}{ll}
\operatorname{Tr} & =\text { The function of time } \\
\mathrm{Yn} & =\text { Gumbel' reduced mean } \\
\mathrm{Sn} & =\text { Gumbel' reduced standard deviation }
\end{array}
$$

Besides, the equation used for calculation of design rainfall in the Log-Pearson type III method is as follows (15):

$$
\log X_{T}=\overline{\log X}+k \operatorname{tr} . S 1
$$

Where:

$\log X_{\mathrm{T}} \quad=$ design rainfall for $\mathrm{T}$ years return period

$\log X \quad=$ the logarithms average of annual rainfall at station

S1 = standar deviation,

Ktr $=$ frequency coefficient based on skewness values $(\mathrm{Cs})$ for $\mathrm{T}$ years return period (can be determined using a frequency factor table (Haan, 1977)

However, the best fit method that can be applied for design rainfall is based on the values of skewness coefficient (Cs) and kurtosis coefficient (Ck). Table 3 describes the values of $\mathrm{Cs}$ and $\mathrm{Ck}$ that must be fulfilled as a rule in choosing the fittest method for the calculation of design rainfall.

Table 3. Cs and $\mathrm{Ck}$ values for each distribution method

\begin{tabular}{|c|c|c|}
\hline No & Type of Distribution & Rule \\
\hline 1 & Log-Normal method & $\mathrm{Cs}=0$ \\
& & $\mathrm{Ck}=3$ \\
\hline 2 & Gumbel type 1 method & $\mathrm{Cs}=1,14$ \\
& & $\mathrm{Ck}=5,4$ \\
\hline 3 & Log-Pearson type III & others \\
\hline
\end{tabular}


The equations for $\mathrm{Cs}$ and $\mathrm{Ck}$ are following [17]:

$$
\begin{gathered}
C S=\frac{n^{2}}{(n-1)(n-2)}\left[\frac{\sum_{i=1}^{i=n}(X i-\bar{X})^{3}}{n S^{3}}\right] \\
C k=\frac{n^{3}}{(n-1)(n-2)(n-3)}\left[\frac{\sum_{i=1}^{i=n}(X i-\bar{X})^{3}}{n S^{4}}\right]
\end{gathered}
$$

Where:

$$
\begin{array}{ll}
\bar{X} & =\text { the mean value of data } \\
\mathrm{n} & =\text { number of data } \\
\mathrm{S} & =\text { standard deviation } \\
\mathrm{Xi} & =\text { variate value of data }
\end{array}
$$

\subsubsection{Analysis of flood peak discharges}

Flood peak discharges are analyzed based on the results of design rainfall. In this study, flood peak discharges are estimated for $5,10,25,50$, and 100 years return period by adopting Nakayasu Synthetic Hydrograph Unit (SHU) method (17) as follows:

$\mathrm{Qmax}=\mathrm{C} * \mathrm{~A} * \mathrm{Ro} *\left(1 /\left(3.6\left(0.3 \mathrm{Tp}+\mathrm{T}_{0.3}\right)\right)\right.$

Where :

Tp is peak time (hour)

$\mathrm{C}$ is runoff coefficient

Ro is designed rainfall ( $\mathrm{mm})$

$\mathrm{A}$ is the catchment area $\left(\mathrm{km}^{2}\right)$

$\mathrm{T}^{0.3}$ is the time of slowdown the discharge (until 30\%)

\section{Results and Discussion}

\subsection{Analysis Results of Average Annual Rainfall}

Table 4 presents the average annual rainfall calculated using the Thiessen method.

Table 4. Analysis results of average annual rainfall

\begin{tabular}{|c|c|c|c|c|}
\hline No & $\begin{array}{c}\text { Type of } \\
\text { Distributi } \\
\text { on }\end{array}$ & Rule & $\begin{array}{c}\text { Analysis } \\
\text { results }\end{array}$ & Notification \\
\hline \multirow{2}{*}{1} & \multirow{2}{*}{$\begin{array}{l}\text { Log- } \\
\text { Normal }\end{array}$} & $\mathrm{Cs}=0$ & 0,7860 & \multirow{2}{*}{$\begin{array}{l}\text { Not } \\
\text { acceptable }\end{array}$} \\
\hline & & $\mathrm{Ck}=3$ & 3,0005 & \\
\hline \multirow{2}{*}{2} & \multirow{2}{*}{ Gumbel 1} & $\mathrm{Cs}=1,14$ & 0,7860 & \multirow{2}{*}{$\begin{array}{l}\text { Not } \\
\text { acceptable }\end{array}$} \\
\hline & & $\mathrm{Ck}=5,4$ & 3,0005 & \\
\hline \multirow{2}{*}{3} & \multirow{2}{*}{$\begin{array}{l}\text { Log } \\
\text { Person III }\end{array}$} & \multirow{2}{*}{ Others } & 0,7860 & \multirow{2}{*}{ Acceptable } \\
\hline & & & 3,0005 & \\
\hline
\end{tabular}

\begin{tabular}{|l|l|l|l|l|}
\hline No & Year & $\begin{array}{l}\text { Rainfall } \\
\text { at Bayah } \\
\text { Station } \\
(\mathbf{2 4 \% )}\end{array}$ & $\begin{array}{l}\text { Rainfall at } \\
\text { Cibeber } \\
\text { Station } \\
\mathbf{( 7 6 \% )}\end{array}$ & $\begin{array}{l}\text { Average } \\
\text { Annual } \\
\text { Rainfall } \\
(\mathbf{m m})\end{array}$ \\
\hline 1 & 2011 & 32.88 & 57 & 89.88 \\
\hline 2 & 2012 & 30.72 & 69.16 & 99.88 \\
\hline 3 & 2013 & 44.4 & 85.12 & 129.52 \\
\hline 4 & 2014 & 29.04 & 73.72 & 102.76 \\
\hline 5 & 2015 & 24.24 & 53.96 & 78.2 \\
\hline 6 & 2016 & 27.6 & 70.68 & 98.28 \\
\hline 7 & 2017 & 28.8 & 53.96 & 82.76 \\
\hline 8 & 2018 & 31.44 & 97.28 & 128.72 \\
\hline 9 & 2019 & 26.88 & 152.76 & 179.64 \\
\hline
\end{tabular}

\subsection{Estimation of Design Rainfall}

Table 5 shows the values of $\mathrm{Cs}$ and $\mathrm{Ck}$ that have been calculated from each distribution method.
Table 5. The values of $\mathrm{Cs}$ and $\mathrm{Ck}$ for each distribution method

Based on Table 5, it can be concluded that the method of Log-Pearson type III is the most suitable fit method that can be applied to determine the design rainfall in the Cimadur river basin. The values of design rainfall for the estimated T-year return period based on the Log-Pearson type III method are presented in Table 6 .

Table 6. Design rainfall using Log-Pearson Type III method

\begin{tabular}{|c|c|c|}
\hline No & $\begin{array}{c}\text { Years return } \\
\text { period }\end{array}$ & $\begin{array}{c}\text { The values of design } \\
\text { Rainfall }\end{array}$ \\
\hline 1 & 2 & 100.20 \\
\hline 2 & 5 & 128.92 \\
\hline 3 & 10 & 153.42 \\
\hline 4 & 25 & 191.19 \\
\hline 5 & 50 & 224.70 \\
\hline 6 & 100 & 263.30 \\
\hline
\end{tabular}

\subsection{Analysis Results of Flood Peak Discharges}

Fig. 4 shows the estimation of flood peak discharges for $2,5,10,25,50$, and 100 years return period by adopting Nakayasu Synthetic Hydrograph Unit (SHU) method (Fig. 4).

Based on Fig. 4, it can be demonstrated that the flood peak discharges in the catchment of Cimadur river for 2 , $5,10,25,50$, and 100 years return periods are $398 \mathrm{~m}^{3} / \mathrm{s}$, $470.71 \mathrm{~m}^{3} / \mathrm{s}, 560.16 \mathrm{~m}^{3} / \mathrm{s}, 698 \mathrm{~m}^{3} / \mathrm{s}, 820.4 \mathrm{~m}^{3} / \mathrm{s}$, and $1017.04 \mathrm{~m}^{3} / \mathrm{s}$, respectively. The flood peak discharges are found to be high even for 5 years return period of design rainfall. The results also show that the peak discharges occur after 4-hour rain continuously.

As reported by RPJMD Lebak district (14), local people in the Cimadur river basin mostly make a living as a farmer. Freshwater is always becoming a necessary thing for agriculture activities by local people in the Cimadur catchment, but the freshwater also could cause harvest failure if the farm is flooded with water (for example flooding occurrences around the agriculture areas during the rainy season). 


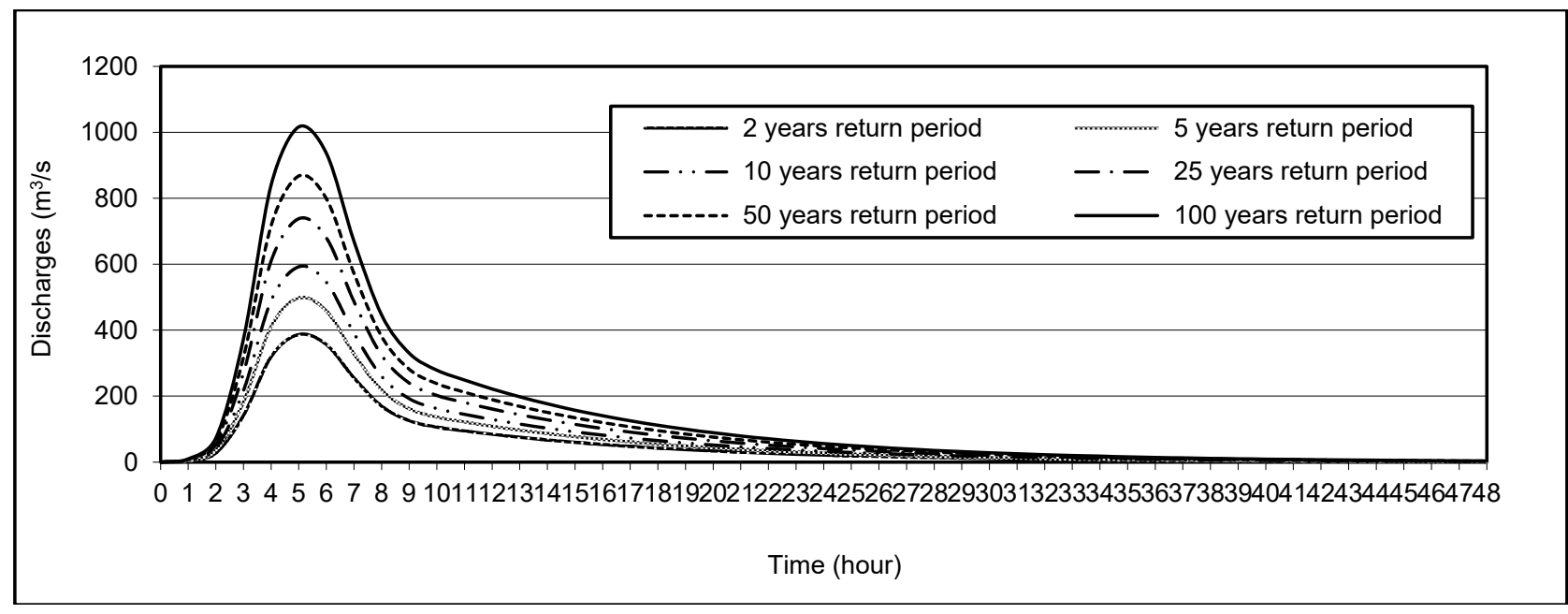

Fig. 4. Flood peaks discharge for 2 years to 100 years return period

Therefore, we have to make sure that the water supply is enough for agriculture activities during the dry season, but no flooding during the rainy season. For this, the local government must think about how to manage and store the excess water during the rainy season to be useful for the farmer during the dry season. The local government may consider constructing an engineering structure that can store and control the excess water discharge during the rainy season.

\section{Conclusion}

Flood is the major natural disaster in the catchment of the Cimadur river for the past few years. Converting the forest to become residential and agricultural areas has triggered more frequency of flooding events. During the rainy season, the flood peak discharges can reach 560.16 $\mathrm{m}^{3} / \mathrm{s}$ for 10 years return period of design rainfall.

However, the agricultural areas in this district will need more water supply during the dry season. High frequency of the water during the rainy season may be utilized for water supply during the dry season. For this, purpose, the local government must think carefully about how to reduce and control the flood problem in the Cimadur catchment and also could plan how to restore the excess water during the rainy season.

The authors would like to extend a special thanks to Universitas Teknokrat Indonesia for supporting in the process of completing this study.

\section{References}

1. H. Chen, L. Yao, A. Fitri, The influence mechanism research of inflow temperature in different time scale on the water temperature structure. In: IOP Conference Series: Earth and Environmental Science. 12058 (2019)

2. R. Hashim, C. Roy, S. Shamshirband, S. Motamedi, A. Fitri, D. Petković, et al. Estimation of WindDriven Coastal Waves Near a Mangrove Forest Using Adaptive Neuro-Fuzzy Inference System. Water Resour Manag. 30 (7):2391-404 (2016)
3. A. Fitri, R. Hashim, S. Motamedi, Estimation and validation of nearshore current at the coast of Carey Island, Malaysia. Pertanika J Sci Technol. 25 (3):1009-18 (2017)

4. A. Fitri, R. Hashim, S. Abolfathi, K. N. A. Maulud Dynamics of sediment transport and erosiondeposition patterns in the locality of a detached lowcrested breakwater on a cohesive coast. Water (Switzerland). 11 (8) (2019)

5. A. Fitri, Z. A. Hasan, A. A. Ghani, Determining the Effectiveness of Harapan Lake as Flood Retention Pond in Flood Mitigation Effort. In: In Proceedings of 2011 4th International Conference on Environmental and Computer Science (ICECS 2011). (2011)

6. S. Hutapea, Biophysical Characteristics of Deli River Watershed to Know Potential Flooding in Medan City, Indonesia. J Rangel Sci. 10(3):316-27 (2020)

7. A. Fitri, R. Hashim, S. Abolfathi, K. N. A. Maulud Dynamics of sediment transport and erosiondeposition patterns in the locality of a detached lowcrested breakwater on a cohesive coast. Water (Switzerland). 11 (8):1721 (2019)

8. L .Yao, X. Huang, A. Fitri, Influence scope of local loss for pipe flow in plane sudden expansions. In: IOP Conference Series: Earth and Environmental Science. 12056 (2019)

9. A. Fitri, K. N. Abdul Maulud, D. Pratiwi, A. Phelia, F. Rossi, N. Z. Zuhairi,Trend Of Water Quality Status In Kelantan River Downstream, Peninsular Malaysia. J Rekayasa Sipil. (2020)

10. A. Fitri, K. Nizam, A. Maulud, F. Rossi, F. Dewantoro, N. Z. Zuhairi, Spatial and Temporal Distribution of Dissolved Oxygen and Suspended Sediment in Kelantan River Basin. In: In 4th International Conference on Sustainable Innovation 2020-Technology, Engineering, and Agriculture (ICoSITEA 2020). Atlantis Press. 51-4 (2021)

11. S. H. Lai, A. Fitri, Application of SWAT Hydrological Model to Upper Bernam River Basin (UBRB), Malaysia. IUP J Environ Sci. 5(2) (2011) 
12. D. Pratiwi, R.O. Sinia, A. Fitri, Increasing Public Knowledge of Porous Drainage Functioning as a Rainwater Infiltration Place. J Soc Sci Technol Community Serv. 1(2) (2020)

13. R. Hashim, A. Fitri, S. Motamedi, A. M. Hashim Modeling of coastal hydrodynamic associated with coastal structures: A review. Malaysian J Sci. 32(4):149-54 (2013)

14. A. Fitri, R. Hashim, K. Song Il, Motamedi S. Evaluation of Morphodynamic Changes in the Vicinity of Low-Crested Breakwater on Cohesive
Shore of Carey Island, Malaysia. Coast Eng J. 57(04):1550023 (2015)

15. A. Fitri, L. Yao, B. Sofawi, Evaluation of mangrove rehabilitation project at Carey Island coast, Peninsular Malaysia based on long-term geochemical changes. In: IOP Conference Series: Earth and Environmental Science. 12055 (2019)

16. RPJMD. Yearly Planning Programme and Report. (2019)

17. Limantara, I L M 2018 Hydrological Engineering: Revised Edition of Andi Publisher. (2018) 